Stevin A. Dubin MD, Holly G. Jense MD, Jody M. McCranie RN MSN, Victor Zubar BA

\title{
Sugarless gum chewing before surgery does not increase gastric fluid volume or acidity
}

\begin{abstract}
Patients occasionally arrive in the operating suite chewing gum despite instructions to avoid oral intake for a specific number of hours before surgery. Some anaesthetists are hesitant to proceed with these patients fearing an increase in gastric volume and acidity. This study was undertaken to determine if gum chewing increased gastric volume and acidity. Seventy seven patients were recruited and informed consent obtained. Thirtyone patients who fasted overnight were randomly assigned either to serve as control (Group 1) or to chew sugarless gum prior to anaesthesia (Group 2). The remaining 46 patients fasted overnight but were given sugarless gum and allowed to chew it until immediately before induction of anaesthesia if they desired (Group 3). Volume and $\mathrm{pH}$ of gastric content were determined immediately after induction of anaesthesia and tracheal intubation. Results revealed mean values (range) of gastric volume for Group 1 - $26 \mathrm{ml}$ (9-60), Group 2 - $40 \mathrm{ml}$ (5-93), and Group 3 - $28 \mathrm{ml}$ (4-65). Mean values for $\mathrm{pH}$ (range) were Group 1 - 1.8 (1.0-4.6), Group 2 - 1.6 (1.3-1.9), Group 3 1.7 (1.0-4.4). There was no difference between groups in terms of gastric volume or $\mathrm{pH}$. In addition, there was no relationship between gastric content and the length of time from gum discard to induction or the length of time gum was chewed. In conclusion, the data suggest that induction of anaesthesia is safe and surgery does not need to be delayed if a patient arrives in the OR chewing sugarless gum.
\end{abstract}

Occasionnellement des patients arrivent à la salle d'opération en mâchant de la gomme contrairement à la consigne du jeûne

\section{Key words}

COMPLICATIONS: aspiration;

GASTROINTESTINAL TRACT: gastric $\mathrm{pH}$, gastric volume, preoperative fluids.

From the Department of Anesthesiology, Medical College of Georgia, Department of Anaesthesia, Augusta GA 30912.

Address correspondence to: Dr. Stevin A. Dubin,

Department of Anesthesiology, Medical College of Georgia, Augusta GA 30912. Fax 706-721-7753.

Presented in part at the Annual Meeting of the American Society of Anesthesiologists 1990.

Accepted for publication 24th March, 1994. absolu spécifié pour un nombre dheures avant la chirurgie. Certains anesthésistes hésitent à anesthésier ces patients parce qu'ils redoutent l'augmentation du volume et de l'acidité gastriques. Cette étude vise à déterminer si la gomme à mâcher augmente le volume et l'acidité gastriques. Soixante-dix patients consentants sont inclus dans l'étude. Trente-et-un patients sont gardés à jeun pour la nuit et répartis au hasard soit pour servir de contrôle (groupe 1) ou pour mâcher de la gomme sans sucre avant l'anesthésie (groupe 2). Les quarante-six autres restent à jeun pendant toue le nuit mais ont la permission de mâcher de la gomme sans sucre jusqu'à linduction de l'anesthésie s'ils le désirent (groupe 3). Le volume et le pH gastriques sont mesurés immédiatement après linduction de l'anesthésie et lintubation de la trachée. Les résultats révèlent les valeurs moyennes de volume gastrique (étendue des valeurs) suivantes: groupe 1 - 26 (9-60); groupe 2 - 40 (5-93), et groupe 3 28 (4-65). Les valeurs moyennes de pH (étendue des valeurs) sont pour le groupe $1-1,8(1,0-4,6)$, groupe 2 - 1,6 (1,3-1,9), groupe $3-1,7(1,0-4,4)$. On ne trouve pas de différence entre les groupes au regard du volume gastrique ou du pH. De plus, il n'y a pas de relation entre le contenu gastrique et lintervalle compris entre l'abandon de la gomme à mâcher et linduction ou le durée du mâchement. En conclusion, ces données suggèrent que l'induction de l'anesthésie n'est pas plus dangereuse et qu'on n'a pas à retarder la chirurgie si un patient arrive en salle d'opération en mâchant de la gomme sans sucre.

Occasionally a patient presents in the operating room chewing gum. This sets up a dilemma for the anaesthetist as to whether to ignore the gum and proceed as usual or to consider the act of chewing gum similar to oral intake and to delay surgery. The assumption of anaesthetists who cancel or delay the case is that gum chewing will increase gastric contents by increasing gastric acid production via the cephalic phase of gastric secretions ${ }^{1}$ and/or by increasing salivary flow ${ }^{2}$ and thus increase the amount of saliva swallowed. This study was undertaken to determine whether this assumption was valid and, if so to determine whether the volume and $\mathrm{pH}$ of gastric contents were related to the time interval from gum discard to induction of anaesthesia. 


\section{Methods}

Approval was obtained from the Institutional Review Board for Human Research. Patients having gastrointestinal disorders, or taking medications known to affect gastric fluid composition or gastric emptying were excluded from the study. Seventy seven ASA physical status I or II patients scheduled for elective outpatient surgery or day of surgery admission were recruited and a written informed consent was obtained. All patients fasted. The first 31 patients were studied to determine the effects of gum chewing on gastric volume and $\mathrm{pH}$ when compared with control. They were divided randomly into two groups. Group 1 - control, group 2 - patients were given sugarless gum to chew upon arrival to the ambulatory surgery unit and were instructed to discard the gum upon call to the operating room, allowing a minimum time of $20 \mathrm{~min}$ between discard and anaesthesia induction.

Once the safety of gum chewing was established, group 3 patients were studied to determine if gastric volume and $\mathrm{pH}$ were related to the time interval between the time the gum was discarded to anaesthesia induction. These patients were given sugarless gum to chew upon arrival to the ambulatory surgery unit. This group of patients was allowed to chew the gum as long as they desired, even until immediately prior to anaesthetic induction.

Anaesthesia induction and maintenance was carried out according to the practice of the anesthesiologist performing the case. After tracheal intubation and muscle relaxation but before skin incision, a $\# 16$ or 18 Salem sump tube was passed into the stomach and the gastric contents were aspirated manually with a $60 \mathrm{ml}$ catheter tip syringe. The patients were tilted side to side and placed in $45^{\circ}$ head down position to facilitate gastric emptying. The $\mathrm{pH}$ of the gastric fluid was immediately determined using a pH monitor (Cole Palmer Model 5985-75 or 5938-00) calibrated before each use. The person aspirating and measuring gastric content was blinded in relation to groups one and two (received gum or did not receive gum) but was not blinded to the patients in group three.

Demographic data, time of induction, time of gum discard, total time gum chewed, gastric aspirate volume, and gastric aspirate $\mathrm{pH}$ were recorded for each patient.

Statistical analysis included Students $t$ test for comparison between groups, analysis of variance with linear regression for time analysis when groups 2 and 3 were combined. Results were considered significant if $P$ was $<0.05$. All data are reported as mean \pm SD.

\section{Results}

A total of 77 patients participated in the study. Sixteen patients were in group 1 - (NPO), 15 patients in group
TABLE I Demographic data (mean \pm standand deviation)

\begin{tabular}{lcccl}
\hline & Group I & Group 2 & Group 3 & $\begin{array}{l}\text { Groups 2 } \\
\text { and 3 }\end{array}$ \\
\hline Gender (M/F) & $5 / 13$ & $4 / 11$ & $13 / 33$ & $17 / 44$ \\
Age (yr) & $27 \pm 6$ & $32 \pm 10^{*}$ & $33 \pm 10^{*}$ & $33 \pm 10^{*}$ \\
Height (cm) & $169 \pm 10$ & $169 \pm 6$ & $167 \pm 12$ & $168 \pm 11$ \\
Weight (kg) & $73 \pm 11$ & $67 \pm 16$ & $72 \pm 16$ & $71 \pm 16$ \\
\hline
\end{tabular}

${ }^{*} P<0.05$ compared to group 1 .

TABLE II Gastric volume and gastric $\mathrm{pH}$ results

\begin{tabular}{lllll}
\hline & Group I & Group 2 & Group 3 & $\begin{array}{l}\text { Groups 2 } \\
\text { and 3 }\end{array}$ \\
\hline Gastric volume (ml) & & & & \\
$\mathrm{N}$ & 16 & 15 & 46 & 61 \\
Mean & 26 & 40 & 28 & 31 \\
Standard deviation & 14 & 30 & 19 & 22 \\
Range & $9-60$ & $5-93$ & $4-65$ & $4-93$ \\
Gastric pH & & & & \\
$\mathrm{N}$ & 16 & 15 & $35^{*}$ & $50^{*}$ \\
Mean & 1.8 & 1.6 & 1.7 & 1.7 \\
Standard deviation & 0.9 & 0.2 & 0.6 & 0.5 \\
Range & $1.0-4.6$ & $1.3-1.9$ & $1.0-4.4$ & $1.0-4.4$ \\
\hline
\end{tabular}

*Data from 11 patients discarded due to malfunctioning equipment.

2 (gum discarded $20 \mathrm{~min}$ before induction) and 46 in group 3 (gum allowed until induction). One patient swallowed the gum but was still included. The $\mathrm{pH}$ recordings of 11 patients were discarded due to malfunctioning of the $\mathrm{pH}$ probe. All the patients fasted for at least eight hours before surgery. Groups 2 and 3 ( $n=61$ pts.) were combined for time analysis calculations.

There were no differences between the three groups in relation to sex, height, or weight. There was a difference in age between group $1(27 \pm 6 \mathrm{yr})$ and groups 2 and $3(32 \pm 10 \mathrm{yr}, 33 \pm 10 \mathrm{yr})(P<0.05)$ but this was considered to be of no clinical importance (Table I).

The mean gastric volumes for group 1,2 and 3 respectively were $26 \pm 14 \mathrm{ml}, 40 \pm 30 \mathrm{ml}, 28 \pm 19 \mathrm{ml}$. The mean gastric pHs for group 1,2 and 3 respectively were $1.8 \pm 0.9,1.6 \pm 0.2 .1 .7 \pm 0.6$. There were no differences between gastric volumes or gastric $\mathrm{pH}$ among groups. Analysis of variance and regression analysis showed no correlation between gastric volume or gastric $\mathrm{pH}$ with interval of time from gum discard to induction. Furthermore, there was no relationship between gastric volume or $\mathrm{pH}$ at anaesthetic induction with the length of time the gum was chewed (Table II).

\section{Discussion}

Fasting for at least eight hours before anaesthetic induction remains the standard care in many institutions. It 
is believed that this will decrease gastric volume and acidity. The duration of this fast has been evaluated recently and many reports now indicate that a period of only two to four hours is adequate for gastric emptying of clear liquids. ${ }^{3-8}$ Commonly patients chew gum despite preoperative teaching to avoid all oral intake. Some anaesthestists have been hesitant to proceed with these patients fearing that the gum will increase gastric content by the cephalic phase of gastric acid production ${ }^{1}$ and/ or by increasing salivary flow. ${ }^{2}$

We found no correlation between gum chewing and gastric volume or acidity. Furthermore there was no relationship with the length of time the gum was chewed nor the time period between gum discard and anaesthetic induction.

Our findings that gum chewing does not affect gastric volume and acidity to any clinically appreciable extent is not unexpected. The digestive period of gastric acid secretion is classically divided into three phases, namely the cephalic, gastric and intestinal phases. The cephalic phase is initiated by sham feedings where food is chewed but is not allowed to enter the stomach, being either spat out or diverted via an oesophageal fistula. The magnitude of this response increases as the duration of the sham feeding increases. The cephalic phase can also be initiated by hypoglycaemia in the brain. The response is mediated via the vagus. Both the gastric and intestinal phases are initiated by distension and by certain compounds entering the respective digestive tract segments. ${ }^{9}$

As early as 1910, Pavlov claimed that a sham feeding of "saline, bitters, pepper (strong local excitation), mustard and so on" did not initiate the cephalic phase of gastric secretion. ${ }^{10}$ Actual food must be used to initiate this response. It is even questionable whether either fat or carbohydrates alone are effective in initiating the cephalic phase of gastric secretion or whether protein is required. ${ }^{9}$ Gum chewing does not fall into any of the above categories.

Saliva production from mastication has been reported to be as high as 5 to $8 \mathrm{ml} \cdot \mathrm{min}^{-1}$ for a sour taste ${ }^{11}$ which, if swallowed, would increase gastric volume. On the other hand, with a pH of $6.0-7.4^{11}$ increasing the amount of saliva swallowed would neutralize gastric acid which should be beneficial. Our results showed that the possible increase in swallowed saliva is not clinically important.

A limitation of the protocol was the use of sugarless instead of sugar-containing gum. One can claim that the sugar (sucrose) in regular gum will be more of a salivary and gastric stimulant. Stanley et al. ${ }^{12}$ studied the effects of oral transmucosal fentanyl citrate in a candy matrix (fentanyl lollipop) vs placebo lollipop on gastric content. Their results showed an increase in gastric volume but no effect on $\mathrm{pH}$, however the gastric volumes and $\mathrm{pHs}$ were still within range of those found after no premedication or premedication with a variety of sedative hyponotics. ${ }^{12}$ The lollipops, given within $30 \mathrm{~min}$ of anaesthesia induction, are effectively comparable with gum chewed prior to induction. Both agents increase salivation and stimulate sensory taste receptors and both agents, one sugarless and one sugar-containing, failed to increase gastric volume and acidity in a clinically significant fashion. Similarly, Dawes and Macpherson ${ }^{13}$ showed that sugar-containing gum, sugarless gum and lozenges all have similar effects on salivary flow rates. The results of Stanley et al. ${ }^{12}$ and Dawes and Macpherson suggest our results probably are applicable to sugar-containing gum also.

Bonner ${ }^{2}$ mentions increased salivation from gum may increase the risk of laryngospasm, describing a case where he recovered $500 \mathrm{ml}$ of saliva from a patient who chewed gum. Dawes and Macpherson ${ }^{13}$ reported maximum gum stimulated rates of $6.6 \mathrm{ml} \cdot \mathrm{min}^{-1}$ for the first minute of chewing, but decreasing to $1.5 \mathrm{ml} \cdot \mathrm{min}^{-1}$ within 15 min. The patient described by Bonner, therefore, would have to have not swallowed for almost eight hours in order to accumulate $500 \mathrm{ml}$ saliva. A more likely explanation is that the tactile stimulation from the laryngeal mask airway itself caused increased salivation throughout the length of the case. This has been described with other smooth objects being placed in the mouth, such as a pebble. ${ }^{10,11}$ Our experience during this study was that neither salivation nor incidence of laryngospasm was notably increased.

The last remaining argument for avoidance of gum chewing is the fear of aspirating the gum itself. ${ }^{14,15}$ This can be problematic when the gum is first discovered upon intubation. We have encountered this situation ourselves. However, it was always when we gave standard preoperative orders of nothing by mouth after midnight. In the study population the OR nurses were cognizant that the patient may have chewed gum and always inquired of the patient, if indeed the gum had been discarded. Perhaps, if we routinely allow gum before bringing the patient to the OR, the nurses will not only question the patient about their NPO status but would specifically inquire if they chewed gum and when it was discarded.

A common problem of this protocol and other studies is the method of gastric volume determination. This can be accomplished either by blind aspiration or by dye dilution. Both methods may underestimate the true gastric volume when compared to aspiration via gastroscope, however, both can be used to obtain a fair estimate of gastric volume. ${ }^{16,17}$ We elected to use a large bore multiorificed orogastric tube aspirating into a large syringe. The patients were placed in a head down position and 
rotated right to left in order to minimize the problems of underestimation.

In summary, sugarless gum chewing before anaesthetic induction does not increase the volume or acidity of gastric content and therefore if a patient arrives to the ambulatory surgery unit chewing gum, there is no reason to delay surgery. Perhaps, for patients who chew gum regularly, it may be advisable for them to chew gum to relieve anxiety preoperatively.

\section{References}

1 Mather C. Preoperative drinking and gastric contents (Letter). Br J Anaesth 1993; 70: 702.

2 Bonner SM. A fasted patient? (Letter). Anaesthesia 1992; 47: 916.

3 McGrady EM, Macdonald AG. Effect of the preoperative administration of water on gastric volume and $\mathrm{pH} . \mathrm{Br} \mathrm{J}$ Anaesth 1988; 60: 803-5.

4 Hutchinson A, Maltby JR, Reid CRG. Gastric fluid volume and $\mathrm{pH}$ in elective inpatients. Part 1: coffee or orange juice versus overnight fast. Can J Anaesth 1988; 35: 12-5.

5 Splinter WM, Stewart JA, Muir JG. Large volumes of apple juice preoperatively do not affect gastric $\mathrm{pH}$ and volume in children. Can J Anaesth 1990; 37: 36-9.

6 Maltby JR, Sutherland AD, Sale JP, Shaffer EA. Preoperative oral fluids: is a five-hour fast justified prior to elective surgery? Anesth Analg 1986; 65: 1112-6.

7 Nicolson SC, Dorsey AT, Schreiner MS. Shortened preanesthetic fasting interval in pediatric cardiac surgical patients. Anesth Analg 1992; 74: 694-7.

8 Maltby JR, Lewis P, Martin A, Sutherland LR. Gastric fluid volume and $\mathrm{pH}$ in elective patients following unrestricted oral fluid until three hours before surgery. Can J Anaesth 1991; 38: 425-9.

9 Grossman MI. Regulation of gastric acid secretion, In: Johnson LR (Ed.). Physiology of the Gastrointestinal Tract. New York: Raven Press, 1981; 659-71.

10 Pawlow JP. The Work of the Digestive Glands. (trans. W.H. Thompson) London: Charles Griffen \& Company Limited. 1902: 70.

11 Guyton AC. Textbook of Medical Physiology, 8th ed. Philadelphia: W.B. Saunders Company 1991; 709-25.

12 Stanley TH, Leiman BC, Rawal N, et al. The effects of oral transmucosal fentanyl citrate premedication on preoperative behavioural responses and gastric volume and acidity in children. Anesth Analg 1989; 69: 328-35.

13 Dawes $C$, Macpherson LMD. Effects of nine different chewing-gums and lozenges on salivary flow rate and $\mathrm{pH}$. Caries Res 1992; 26: 176-82.

14 Maltby JR. Chewing gum during the pre-operative fast (Letter). Anaesthesia 1993; 48: 453.

15 Kradel B, Hackett A, Johnstone R. NPO includes chewing gum (Letter). Anesth Analg 1992; 74: 621.
16 Taylor WJ, Champion MC, Barry AW, Hurtig JB. Measuring gastric contents during anaesthesia: evaluation of blind gastric aspiration. Can J Anaesth 1989; 36: 51-4.

17 Hardy JF, Plourde G, Leburn M, Côté C, Dubé S, Lepage $Y$. Determining gastric contents during general anaesthesia: evaluation of two methods. Can J Anaesth 1987; 34: 474-7. 